\title{
Genetically based resistance to summer mortality in the Pacific oyster (Crassostrea gigas) and its relationship with physiological, immunological characteristics and infection processes
}

\author{
J.F. Samain ${ }^{1 \star}$, L. Dégremont ${ }^{2}$, P. Soletchnik ${ }^{3}$, J. Haure $^{4}$, E. Bédier ${ }^{5}$, M. Ropert $^{6}$, J.Moal $^{1}$, A. \\ Huvet $^{1}$, H. Bacca ${ }^{1}$, A. Van Wormhoudt ${ }^{10}$, M. Delaporte ${ }^{1}$, K. Costil ${ }^{9}$, S. Pouvreau ${ }^{1}$, C. \\ Lambert $^{11}$, V. Boulo ${ }^{7}$, P. Soudant ${ }^{11}$, J.L. Nicolas ${ }^{1}$, F. Le Roux ${ }^{2}$, T. Renault ${ }^{2}$, B. Gagnaire ${ }^{2}$, \\ F.Geret ${ }^{8}$, I. Boutet ${ }^{11}$, T. Burgeot ${ }^{8}$, P. Boudry ${ }^{2}$.
}

${ }^{1}$ UMR 100 Physiologie et Ecophysiologie des Mollusques Marins, Ifremer, Centre de Brest, B.P 70, 29280 Plouzané, France;

${ }^{2}$ Laboratoire de Génétique et Pathologie, Ifremer, 17390 La Tremblade, France;

${ }^{3}$ Laboratoire Environnement Ressources des Pertuis Charentais, Ifremer, 17390 La Tremblade, France,

${ }_{5}^{4}$ LER Pays de Loire, Polder des champs, 85230 Bouin, France,

${ }^{5}$ Laboratoire Environnement Ressources Morbihan Pays de la Loire, Ifremer, 56470 La Trinité, France;

${ }^{6}$ Laboratoire Environnement Ressources de Normandie, Ifremer, BP 32, 14520 Port en Bessin, France,

${ }^{7}$ Laboratoire GPIA 2 Place E. Bataillon, Université de Montpellier, CC80, F-34095 Montpellier cedex 5, France,

8 Laboratoire d'Ecotoxicologie, Ifremer, BP 21105, 44311 Nantes cedex 03, France,

${ }^{9}$ UMR 100 Physiologie et Ecophysiologie des Mollusques Marins, Université de Caen, Esplanade de la Paix, 14032 Caen Cedex, France,

10 UMR 5178, Station de Biologie Marine du Muséum National d'Histoire Naturelle, BP225, 29900 Concarneau, France;

11 LEMAR IHP and RSA, Institut Universitaire Européen de la Mer, Université de Bretagne Occidentale, 29280 Plouzané France.

* Corresponding author: ifsamain@ifremer.fr

\begin{abstract}
:
Summer mortality of Pacific oysters is known in several countries. However no specific pathogen has been systematically associated with this phenomenon. A complex combination of environmental and biological parameters has been suggested as the cause and is now starting to be identified. A high genetic basis was found for survival in oysters when a first generation (G1) was tested in three sites during summer. This paper presents a synthesis on physiological characteristics of two selected groups (' $R$ ' and ' $S$ ', from families selected for resistance and susceptibility to summer mortality respectively), of the second and third generations. $R$ and $S$ showed improvement or reduction of survival compared with the control in both field and laboratory trials confirming the high heritability of survival of juveniles $<1$ year old. Interestingly, no correlation was observed between growth and survival.
\end{abstract}


Comparison between the two selected groups showed that $S$ oysters invested more energy in reproduction and stayed a longer time without spawning than $\mathrm{R}$ oysters which had high synchronous spawning. This was mainly shown with high rather than low dietary rations (respectively $12 \%$ and $4 \%$ DW algae/DW oyster) in a controlled experiment. Moreover, early partial spawning was detected in $\mathrm{S}$ oysters and not $\mathrm{R}$ ones in the high dietary ration. $\mathrm{S}$ showed a higher respiration rate and an earlier decrease in absorption efficiency than $\mathrm{R}$ during gametogenesis, but they were not significantly different in glycogen or ATP utilisation. Two months before a mortality episode, hemocytes from S oysters had a higher adhesive capacity than $\mathrm{R}$ hemocytes and significantly higher reactive oxygen species production capacity. One month before mortality, $\mathrm{S}$ oysters had the highest hyalinocyte concentration and their expression of genes coding for glucose metabolism enzymes (Hexokinase, GS, PGM, PEPCK) was significantly lower in the labial palps. After a thermal increase from $13{ }^{\circ} \mathrm{C}$ to $19^{\circ} \mathrm{C}$, during 8 days in normoxia, S oysters showed a large HSP70 increase under hypoxia contrary to $\mathrm{R}$ oysters, suggesting their high susceptibility to stress. Their catalase activity was lower than in $\mathrm{R}$ oysters and showed no further change to subsequent hypoxia and pesticide stresses, in contrast to $\mathrm{R}$ oysters.

These observations suggest possible links between higher reproductive effort in S oysters, their specific stress response to temperature and hypoxia, ROS production, partial spawning, hyalinocyte increase and the infection process. To compare $\mathrm{R}$ and $\mathrm{S}$ oysters in a more integrated way, a suppression subtractive hybridisation (SSH) library and a micro-array strategy are being undertaken.

Keywords: Summer mortality; Pacific Oyster; Crassostrea gigas; Resistant oyster; Genetic selection; Reproduction; Hemocytes; Stress; Temperature; ROS 


\section{Introduction}

According to Koganezawa (1974), the phenomenon known as Crassostrea gigas "summer mortality" first began along the Japanese Pacific coast in 1945. Features common to mortality episodes were elevated temperature, full maturation or spawning and high trophic conditions. The relationship between gonadal maturation, energy metabolism, and the mortalities was investigated (Koganezawa, 1974, Mori, 1979) and it was concluded that summer mortality in Japan was due to a "physiological disorder and metabolic disturbance derived by heavy gonad formation and massive spawning under high water temperature and eutrophication" (Koganezawa, 1974). In the late 1950s, mortalities of $C$. gigas were first noted on the west coast of USA (Glude 1975, Cheney et al., (2000). Experimental studies further implicated gonadal maturation and loss of carbohydrate reserves (Perdue et al., 1981). Lipovsky and Chew (1972) showed experimentally that rising temperature (up to $21^{\circ} \mathrm{C}$ ) or high levels of microalgae significantly increased mortality. Different pathogens were isolated but none of them could explain summer mortality (Elston et al., 1987, Friedman et al., 1998, 1991, 2005). In France, oyster production has experienced periodical mass mortalities for the last 20 years (Renault et al., 1994; Goulletquer et al,. 1998; Soletchnik et al., 1999). Results have confirmed that summer mortality is the result of multiple factors including elevated temperature, physiological stress associated with maturation, aquaculture practices, pathogens, pollutants, etc... (Soletchnik et al., 1997, 2005a, Goulletquer et al., 1998, Le Roux 2002, 2004, Gay et al., 2004a). Despite inter-annual and interlivestock variability, mortality of oysters reared on the sediment (or a few centimetres above) was significantly higher (20-30\%) than mortality of animals on tables (iron frames) (Soletchnik et al., 1999, 2003, 2005b). The Morest project on C. gigas oyster summer mortality (2001-2005) progressively classified the importance of these different factors by coupling field and experimental studies (Samain et al., 2004a, 2004b, Soletchnik et al., 2005b). Summer mortality has also been described in cultured eastern oysters, $C$. virginica, on the north-eastern coasts of the USA where a disease named Juvenile Oyster Disease (JOD) was reported. This disease only affects juvenile ( $<1$ year old) and fast growing oysters when seawater temperature exceeds $20^{\circ} \mathrm{C}$ and plankton blooms occur (Lee et al., 1996). JOD can cause the death of up to $90 \%$ of affected stocks within a few weeks (Bricelj et al., 1992; Ford and Borrero, 2001). Studies have shown a genetic basis for the resistance to JOD allowing the production of resistant strains (Lewis et al., 1996).

Increasing stress and disease tolerance of economically important species has long been considered feasible through selective breeding. For oysters, genetic variability is thought to be a major determinant in sensitivity to summer mortality (Hershberger et al., 1984). Selected families produced in a breeding program showed greatly improved survival both in the field and in elevated-temperature laboratory trials (Beattie et al., 1980). However these selected stocks appeared thinner, smaller and had slower growth than unselected stocks. During the Morest project, Dégremont et al. (2005) showed that $45 \%$ of the observed variance in mortality in the field was due to variation among families. Such resistance, against a complex of factors affecting survival, is a very attractive model for understanding biological resistance mechanisms. Moreover, natural populations are likely to be under selective pressure and consequently eliminate susceptible oysters. However, these observations suggest a possible difference in fitness and adaptation between resistant and susceptible oysters in different environments. In this paper, we describe the results of divergent selection based on these criteria, and present a review of the main biological aspects associated with resistance or susceptibility, by comparison of field and experimental data from different disciplines.

\section{Material and Methods}

\subsection{Biological material}

A first generation (G1), constituted of 44 full-sib families and 17 half-sib families, was produced following a hierarchical mating design in 2001 as described by Dégremont et al. (2005). Oysters were deployed and tested until October 2001 in Rivière d'Auray located in South Brittany in France $\left(2^{\circ} 57^{\prime} \mathrm{W}\right.$ $47^{\circ} 36^{\prime} \mathrm{N}$ ). According to their mean survival performances, 3 half-sib families (each constituted of 3 fullsib families) showing high survival and 3 showing high mortality were selected. In a second step, the two best and two worst full-sib families were selected out of 3 within each half-sib family. Due to a distribution of survival of the tested G1 families skewed, the resulting selection intensity was stronger for the low selected group $(S=-26.5)$ than for the high one $(S=11.8)$. In all cases, oysters used as parents to generate the following generations were not deployed in the field but kept in a nursery and consequently did not experience summer mortality. In 2002, 9 and 10 batches were produced from the 
high and low selected groups respectively using in average 53 oysters ( 27 males and 26 females) per G1 selected families and avoiding crossing related individuals. These 2 selected groups of the second generation (G2) are referred to hereafter as ' $R$ ' and ' $S$ ' for progeny from parents respectively 'resistant' and 'susceptible' to summer mortality. All batches were placed in Rivière d'Auray and mortality was recorded during summer 2002. Additionally, G1 oysters from the 12 selected families were also crossed within each family (mean number of males per family $=28$; mean number of females per family $=30$ ) to generate inbreed families. Oysters from these families, were used in 2003 to generate a third generation (G3) and was produced by crossing individuals (mean number of males and females = 23) among families, replicating the two G2 "R" and "S" groups. G3 progenies were also tested in Rivière d'Auray during summer 2003.

Control groups were produced as follows. In 2001, gametes of all parental oysters used to produce G1 families of each hatchery group were pooled to constitute three multi-parental G1 groups. In 2002, crosses among those groups (i.e. avoiding any inbreeding) were performed to generate a G2 control group. In 2003, a G3 control group was produced by crossing 17 female and 10 male oysters collected from the wild in the Marennes-Oléron Bay (France).

\subsection{Controlled diet experiment}

One-year-old $G 2$ oysters from three families with the R phenotype and two families with the $S$ phenotype were respectively mixed to form $R$ and $S$ stocks. These were kept at the IFREMER shellfish laboratory in Argenton (Finistère, France) from April to September 2003, in separate 700-L raceways. The $\mathrm{R}$ and $\mathrm{S}$ oysters were each divided into two groups and fed either $4 \%$ or $12 \%$ algal dry weight (DW) per oyster dry weight (termed as $4 \%$ and $12 \%$ diets respectively) and kept at MarennesOléron mean temperatures and photoperiod cycles as described in Enriquez-Diaz, (2004). Continuous records of $\mathrm{pH}$, temperature, oxygen, salinity, turbidity (Endress et Hauser), florescence (Seapoint) and flow rate were performed in the different tanks, using an adapted multi-parameter probe system called MAREL (Ifremer-NKE). This allowed to control the stability of the different environmental conditions tested (Bourles, 2004) and provided in real time the necessary data to estimate R and S energy balance in the two trophic conditions. Tanks and oysters were cleaned daily, which allowed the assessment of oyster mortality on a daily basis over the whole experiment. Spawning was induced at the end of August by thermal shock. Oysters $(n=20)$ were sampled monthly or twice a month for biochemical, and haemocyte parameters.

\subsection{Semi-quantitative histology}

The length of the visceral mass was measured for each oyster, then the mass was divided into three equal portions. Sections of $5 \mu \mathrm{m}$ were cut at three representative body levels (see Enriquez-Diaz, 2004 for details). These were fixed in Davidson's solution (Shaw and Battle, 1957) and dehydrated in an ascending alcohol series for wax embedding. They were mounted and stained in Harris hematoxylin and counter-stained in eosin $Y$ following the standard method proposed by Martoja and MartojaPierson (1967). Percentages of gonad and digestive areas (GA and GD, respectively) were then determined on each histological section. Slides were scanned with a digital scanner (hp scanjet 7400c) and the images saved in *.TIFF format. Tissue areas were then measured using image analysis software (Imaq Vision Builder, National Instruments Corp.). Gonad area percentage was estimated as pixel number from gonad / pixel number from total section.

\subsection{Measurement of ingestion, assimilation and respiration rates}

From June to August, water flowing in and out of each raceway was periodically sampled for phytoplankton and oxygen concentration measurements. According to the flow rate in each raceway, these concentrations were used to calculate ingestion (C, J.h.g . $^{-1}$ ) and $\mathrm{O}_{2}$ consumption rate $(R$, $\mathrm{mgO}_{2} \cdot \mathrm{h}^{-1} . \mathrm{g}$ ) (Enriquez-Diaz, 2004). Bio-deposits were collected periodically to estimate the absorption efficiency $(A E, \%)$, measured by the Conover ratio (Conover, 1966): AE= F-E/[(1-E)xF], where $A E=$ Absorption efficiency; $F=$ Organic content of the food; $E$ = Organic content of faeces.

\subsection{Biochemical composition}

At each sampling date, biochemical analyses were performed on 10 individual oysters as described in Delaporte et al. (2006). Individual animals were frozen in liquid nitrogen $\left(-196{ }^{\circ} \mathrm{C}\right)$ and ground with a 
Dangoumeau homogeniser. A known amount of frozen homogenate was used for the different analyses. Total carbohydrate content was measured as described by Dubois et al. (1956). Results were expressed as percentage of oyster dry tissue weight.

Adenylate Energy Charge (AEC) analyses were realised on the same powder used for dry weight measurement and biochemical analyses, according to Moal et al. (1989). AEC, which represents an estimation of the "instantaneous" cellular energy available, was calculated as: AEC $=(A T P+0.5$ ADP $) /(A T P+A D P+A M P)$, which varies between 0 and 1.

\subsection{Quantification of relative gene expression}

For gene expression analysis, 4 pools of 5 oysters were collected every month. The data reported here are from June. Labial palps were dissected and lysed in RNA extraction buffer (Extract-all, Eurobio). Total RNA was isolated using the Eurobio procedure, and polyadenylated RNAs were reverse-transcribed from $1 \mu \mathrm{g}$ of total RNA denatured for $10 \mathrm{~min}$ at $70^{\circ} \mathrm{C}$ as described in Bacca et al. (2005).

The detection and relative quantification of hexokinase (HK), phosphoglucomutase (PGM), pyruvate kinase (PK), phosphoenol pyruvate kinase (PEPCK), glycogen synthase (GS) and glycogen phosphorylase (GP) mRNA were carried out by real time PCR using SYBR Green chemistry. Amplification of glucose-6-phosphate dehydrogenase cDNAs was performed in order to confirm the steady-state level of expression allowing an internal control for gene expression. Specific primers used for amplification are indicated in table 1. Real time PCR was performed, as described in Bacca et al. (2005), allowing the calculation of the relative quantity of target mRNAs. PCR efficiencies were determined for each primer pair by determining the slope of standard curves obtained from serial dilution analysis of cDNA.

\subsection{Measurement of hemocyte parameters by flow cytometry}

Various hemocyte parameters were analysed monthly from April to September using a flow cytometer (FACScalibur Becton-Dickinson): hyalinocyte and granulocyte concentrations (cells per $\mathrm{mL}$ ), hemocyte mortality (\%), phagocytosis rate (\% active hemocytes able to engulf more than 3 fluorescent beads in an hour at $18{ }^{\circ} \mathrm{C}$ ) and hemocyte adhesive capacity in sea-water (\% adhesive cells after 3 hours incubation at $18^{\circ} \mathrm{C}$ in sterile sea-water). Additionally, hyalinocyte and granulocyte production of reactive oxygen species (ROS) was evaluated after two hours incubation in sterile sea-water (expressed in arbitrary units). For all these parameters, methods have been previously described (Choquet et al., 2003; Delaporte et al., 2003; Lambert et al., 2003; Delaporte, 2005).

\subsection{Hypoxia stress experiment}

Oysters from the second generation produced in 2002 were stored in the Bouin nursery from May 2002 (Dégremont et al 2005). In December 2002, two 7 day experiments were performed successively under normoxia and hypoxia conditions using a total of $300 \mathrm{R}$ oysters and $300 \mathrm{~S}$ oysters. In each experiment, half of the population was firstly acclimated progressively from the initial nursery temperature $13^{\circ} \mathrm{C}$ to $19^{\circ} \mathrm{C}$ over 6 days, with two more days at $19^{\circ} \mathrm{C}$, and a seawater renewal once a day. Thereafter R and S oysters were exposed in two tanks (1200 L each) under the same room and under the same controlled conditions at $100 \%$ or $30 \%$ oxygen using oxygen or nitrogen respectively (temperature: $19 \pm 1^{\circ} \mathrm{C}$, salinity: $32 \pm 0.5 \mathrm{psu}$ ). Ten $\mathrm{R}$ and ten $\mathrm{S}$ oysters were removed from each treatment for each sampling date (0,1, 3, 7 days). Mantle, digestive gland and gills were dissected, weighed and then frozen in liquid nitrogen and stored at $-80^{\circ} \mathrm{C}$ until analyses of enzyme activities and protein content were made. Only gills in both oxygen concentrations are reported here in example. They were then homogenized in appropriate buffers for the different analyses as described in the publications cited below. HSP70 quantification by ELISA was made as described in Boutet et al. (2003). Catalase (EC 1.11.1.6) (CAT) activity was measured in the gills according to Greenwald (1985). Total protein concentration of the supernatant was measured according to Bradford (1976), using bovine serum albumin as a standard. 


\subsection{Infection challenges and hemolymph bacterial counts.}

Bacterial challenge by injection was performed with strains belonging to Vibrio splendidus or $V$. aestuarinus species as described previously (Gay et al., 2004b, 2004c, Labreuche et al., 2005).

Challenges by the bath method were performed by bathing $3 \times 30$ or $3 \times 20$ oysters per batch in $10^{6}$ cell $\mathrm{ml}^{-1}$ (final concentration) of Vibrio aestuarianus (strain 02/041). Before this challenge, oysters were submitted to temperature shock $\left(40^{\circ} \mathrm{C}\right.$ for 2 hours). The experiment lasted 11 days at $19 \pm 1^{\circ} \mathrm{C}$ and was performed with $\mathrm{R}$ and $\mathrm{S}$ oysters from the field (Rivière d'Auray 2002) and from the two treatments (4\% and $12 \%$ ) of the controlled diet experiment described above.

A survey of bacteria in hemolymph from healthy $\mathrm{R}$ and $\mathrm{S}$ oysters placed in the Rivière d'Auray site was performed in 2002. The oysters were placed in bags on a table at $70 \mathrm{~cm}$ above the sediment. Five animals per batch were sampled every month from May to September. Bacterial concentrations in sterilely withdrawn hemolymph were determined by serial ten-fold dilutions and plating onto Marine Agar.

\subsection{Statistical analysis}

Survival was analysed by a logistic regression using the GENMOD procedure and a log transformation for binomial data using SAS $^{\circledR}$ software (SAS Institute Inc., 1995) following:

$$
\log \left(\frac{S_{i j k}}{1-S_{i j k}}\right)=\alpha_{i}+\beta_{j(i)}+\varepsilon_{i j k}
$$

where $\mathrm{S}_{\mathrm{ijk}}$ is the survival of the spat $\mathrm{k}$ in batch $\mathrm{j}$ nested in group $i$ and $\varepsilon \mathrm{ijk}$ is the error term.

Statistical analyses of growth and yield are described in Dégremont et al. (2005). Briefly, daily yield and growth were analysed using ANOVA and ANCOVA respectively performed by the GLM procedure in the SAS ${ }^{\circledR}$ software. All factors tested were treated as fixed factors because the selected groups and batches were a non-random sample from the entire population. Weight was log-transformed and the time in the field was defined as continuous variable in order that the interaction between time and class represents the growth rate.

Enzymatic activity data were log transformed and analyzed by an ANOVA using Duncan's test for paired multiple comparisons with the software Statistica.

Multifactor analysis of variance (MANOVA) was performed for all biochemical and immune parameters using STATGRAPHICS Plus 5.1 (Statistical Graphs Corp.). Percentage data were transformed (arcsine of the square root) before MANOVA.

\section{Results}

\section{1. $R$ and $S$ mortality, growth and yield}

Mortality, individual weight (initial and final) and yield are presented in table 2. The R group showed much higher survival than the $S$ group and the control group had intermediate survival $(p<0.0001)$ for both generations in Rivière d'Auray (i.e., G2 and G3 from 2002 and 2003 respectively). For example in 2002 for G2, summer mortality of the S oysters was $43 \%$, while it was only $7 \%$ for R oysters and $24 \%$ for the unselected control. Similar results were found in 2003 for $\mathrm{G} 3$ where summer mortality of S was $73 \%$, while it was only $27 \%$ for $\mathrm{R}$ and $48 \%$ for the unselected control. No significant growth difference was found between $\mathrm{R}, \mathrm{S}$ and the control in either generation $(p>0.05)$ A significant effect was observed for the yield though: in G2, R had a daily yield $77 \%$ higher than S, and the control yield was $40 \%$ higher than S (Table 2). Similar results were found for the G3 with the highest daily yield in the R oysters, half as much for the control, and a quarter in the S oysters.

In the controlled diet experiment, a mortality event was recorded. Although cumulative mortality remained below $5 \%$ during the first two months of the experiment, a rapid increase was seen in July (Fig.1), where differences in mortality were shown between groups and treatments. Oysters batches fed the $12 \%$ diet suffered higher mortalities than those fed the $4 \%$ diet, and S oysters had higher mortalities than R oysters. Consequently, a gradient was observed in cumulative mortality: $12 \% \mathrm{~S}>$ $12 \% \mathrm{R}>4 \% \mathrm{~S}>4 \% \mathrm{R}$, from July until the end of the experiment in September.

\subsection{Reproductive strategy}

Quantitative histology performed on R and S oysters, reared in the same field site (Rivière d'Auray) 
showed there was higher reproductive investment in S compared with $\mathrm{R}$ oysters during the first part of gametogenesis. Thereafter, a small decrease in $\mathbf{S}$ gonad index led to similar gonad volume between the groups. R oysters spawned completely in August when maximum temperature reached $20{ }^{\circ} \mathrm{C}$. However, S oysters did not spawn completely and a progressive gamete resorption was observed in fall (Fig. 2). This observation was repeated in 2004, under similar thermal conditions, but not in 2003 when temperature increased sharply to a maximum of $22{ }^{\circ} \mathrm{C}$ and $\mathrm{R}$ and $\mathrm{S}$ oysters spawned synchronously (data not shown).

Under high dietary rations (12\%) in the controlled diet experiment, a large variability in gonad area index was observed for S oysters compared to R ones (Fig. 3). Due to this variability, the only trend clearly shown was an initial higher germinal investment for $\mathrm{S}$ compared with $\mathrm{R}$, followed by a small decrease corresponding to partial spawning of $S$ at the end of June (observed on continuous records of environmental data in the tank). With the low diet (4\%), gonad area index increased less but in a more regular manner than with the $12 \%$ diet and no difference appeared between R and S oysters. In August a thermal stimulation was applied to induce spawning and both S and R oysters in the $4 \%$ diet spawned completely. In the $12 \%$ diet however, only the R oysters spawned completely. R oysters therefore showed the same spawning behaviour in both treatments, whereas an interaction with diet occurred for the S.

\subsection{Energy acquisition and expenditure}

During the dietary experiment, consumption (Fig.4a) was similar between R and S oysters in both diets and increased progressively during summer from 22 to $30 \mathrm{~J} \cdot \mathrm{h}^{-1} \cdot \mathrm{g}^{-1}$ in the $4 \%$ diet and from 60 to $85 \mathrm{~J}^{-1} \mathrm{~h}^{-1} \cdot \mathrm{g}^{-1}$ in the $12 \%$ diet. In contrast, AE (fig.4b) decreased over time reaching a minimum in August particularly for oysters in the $12 \%$ diet. No differences in AE were found between R and S oysters, except at the beginning of the measurements in June for oysters fed the $12 \%$ diet. As for energy use, the respiration rates (fig.4c) were slightly but significantly higher for S compared with $\mathrm{R}$ oysters.

During the same period, the use of energy previously stored for gametogenesis (Total glucose and AEC was similar for R and S oysters whatever the diet (Fig.4d). During the critical period (June) preceding the summer mortality period, levels of mRNA coding for Hexokinase (HK), Phosphoglucomutase (PGM) and Phosphoenolpyruvatecarboxy kinase (PEPCK) were significantly lower for $\mathrm{S}$ oysters than for $\mathrm{R}$ ones $(\mathrm{t}=4.28,4.86$ and 3.20 respectively ; $p<0.05)$ (Fig.5).

\subsection{Hemocyte characteristics}

$\mathrm{R}$ and $\mathrm{S}$ oyster hemocyte parameters were recorded throughout the diet experiment (Delaporte 2005). Hemocyte parameters observed before and during the mortality event in mid July are summarized in Table 3. Whatever the diet concentration, no difference was observed in percentage hemocyte mortality which was low ( $<5 \%$, i.e more than 95\% cell viability) (ANOVA, $p>0.1$ ). The first difference between $\mathrm{S}$ and $\mathrm{R}$ was observed in April (data not shown) and in May where $\mathrm{S}$ oyster hemocytes exhibited a higher adhesive capacity than $\mathrm{R}$ ones (Kruskal-Wallis, $p=0.02$ ). Reactive oxygen species ROS were significantly higher in S than in R oysters in May for both hyalinocyte and granulocyte subpopulations (ANOVA, $p=0.0001$ and $p=0.0036$ respectively), and in June (Kruskal-Wallis, $p=0.015$ and $p=0.035$ ). After July and the major mortality event, ROS decreased and was identical for R and $\mathrm{S}$ oysters. Hyalinocyte concentration increased significantly more for $S$ than for $\mathrm{R}$ oysters in July just before the mortality event (Kruskal-Wallis, $p=0.055$ ).

\subsection{Biomarker response to experimental temperature elevation and stress with hypoxia}

Several biomarkers were tested to investigate the difference in $\mathrm{R}$ and $\mathrm{S}$ oyster stress response. Surprisingly, stress protein levels (HSP70) were different between R and S oysters at J0, after 8 days of acclimation from 13 to $19^{\circ} \mathrm{C}$ in the two independant experiments before normoxia and hypoxia condition ( $p<0.05$ and $P<0,01$ respectively) (Fig.6 left). This difference disappeared rapidly with time in normoxia, with the progressive increase of HSP70 from R oysters. However, in hypoxia, HSP70 from $S$ increased to a high level in 3 and 7 days $(P<0,01)$ as it stayed low and constant whatever the condition for R. Catalase activity (Fig 6 right) was very stable for S oysters, whatever the condition. It was also quite stable for $R$ oysters, but their level was significantly higher $(p<0,05)$. 


\subsection{Experimental infections and field analyses}

Similar mortality levels were observed in both $\mathrm{R}$ and $\mathrm{S}$ from the field after injection of virulent strains of $V$. splendidus or V. aestuarianus into the oyster muscles (Nicolas pers. comm. Gay 2004b). A significantly higher susceptibility of $\mathrm{S}$ compared with $\mathrm{R}$ oysters was however observed in May when animals of 15 months from Rivière d'Auray were submitted to a heat shock stress followed by a $V$. aestuarianus bath challenge. This difference was not observed for younger $\mathrm{R}$ and $\mathrm{S}$ spat of 4 months from the same site (Fig.7). Using the same bacterial bath challenge but with animals from the controlled diet experiment, high mortality and differential responses were observed between $\mathrm{R}$ and $\mathrm{S}$ with the $12 \%$ diet $(p<0.05)$. A lower mortality was observed at $4 \%$ diet with no difference between $R$ and S (Fig.7).

During May and June, bacterial concentrations in the hemolymph of apparently healthy oysters from Rivière d'Auray, increased to $10^{5} \mathrm{ml}^{-1}$, then decreased to very low levels $\left(<10^{2}\right)$ after the mortality event (Fig.8). During the period of bacterial increase, concentrations tended to be higher in S oysters than in $\mathrm{R}$ ones, although these differences were not significant.

\section{Discussion}

\subsection{Genetic effect}

$\mathrm{R}$ oysters demonstrated a better survival than $\mathrm{S}$ oysters indicating a positive response to selection for survival. These findings, combined with similar growth observed for the two selected groups and the unselected control, gave a overall higher yield for R compared with $\mathrm{S}$, and intermediate yield in the control. Langdon et al. (2003) reported that yield is a heritable trait, but without distinguishing the relative influence of survival and growth. In Rivière d'Auray, survival explains most of the yield variability (Dégremont et al., 2005) indicating that survival is the most important parameter to improve in sites showing high summer mortality. Such results were repeated over 3 successive generations leading to the conclusion that a family-based selection program could be useful to develop summer mortality resistance in the field at the spat stage. The high heritability for survival also suggests that only a few genes are involved for survival in oysters under one year old.

\subsection{Reproductive strategy}

An overview of the results comparing $\mathrm{R}$ and $\mathrm{S}$ oysters in the field and in experimental conditions, would suggest that a difference in reproductive strategy is a key point for resistance. An apparently higher germinal investment in the S oysters compared to $\mathrm{R}$ ones observed in the field was reproduced under controlled experimental conditions when oysters were fed the high (12\%) diet. A possible genetic difference in energy allocation to reproduction between the two groups when faced with the different diets could explain this divergence. Food availability, energy balance and reproduction are strongly related in many organisms, such as vertebrates, through complex regulatory factors (Schneider 2004). Among them, the neuropeptide Y (NPY) acts as a switch for appetite, sex and reproduction (Kalra and Kalra, 2001). It has also been detected in invertebrates (de Jong-Brink, 2001), and represents a possible line of investigation into genetic differences in reproductive strategy.

Partial spawning characterized $S$ under experimental conditions with rapid re-maturation processes explaining the observed fluctuations in $\mathrm{S}$ gonad quantitative histology seen in the field. Complete spawning was not obtained in experimental conditions for S oysters fed the $12 \%$ diet under classical heat shock induction. These results confirm field observations as $S$ oysters did not have one major spawning, but partial spawnings observed at temperatures between 19 and $21^{\circ} \mathrm{C}$ about a month before the major spawning of the $\mathrm{R}$ oysters. This could represent a difference in sensitivity to temperature between the two groups because in 2003 , when temperature in the field increased above $21^{\circ} \mathrm{C}$, both groups had complete synchronous spawning (data not shown). Differences in spawning strategy and spawning induction by biotic or abiotic factors are another way in which R and S oysters could be genetically compared.

Differences in reproductive strategy could reflect differences in fitness between the $\mathrm{S}$ and $\mathrm{R}$ groups, but this difference would vary according to environmental conditions which might explain why $S$ oysters are not always counter-selected in the wild. 


\subsection{Reproduction intensity and energy balance}

As reported by Koganezawa (1974), Mori (1979) and Perdue et al. (1981), mortality was associated with high reproductive activity when glycogen reserves decreased and reached low points just before mortality events. Such depletion of reserves would possibly lead to energetic imbalances if temperature then increased. Recently, Pouvreau et al. (2003), and Enriquez-Diaz (2004) demonstrated, using an oyster population with a large genetic base, that an increase in dietary ration during the reproductive period induced a higher investment in gametogenesis. However, there was also a higher susceptibility to experimental infection than with a low diet (Gay 2004c). Lipovsky and Chew (1972) previously showed that adding high doses of microalgae to tank seawater significantly increased mortality. Working on different phenotypes, our findings are similar to these previous results, showing that in the $12 \%$ diet, $\mathrm{S}$ oysters exhibited a higher investment in gametogenesis but also a higher susceptibility to mortality compared with the $4 \%$ diet and $\mathrm{R}$ oysters. This antagonistic correlation between reproductive investment and survival when food is abundant was also reported by Ernande et al. (2004). At the other end of the scale, when food is scarce, survival is favoured. The higher investment in gametogenesis in the $S$ oysters is demonstrated through a higher respiration rate compared with $\mathrm{R}$ oysters and probably corresponds to higher biosynthetic activity. Assimilated energy was equivalent between $S$ and $R$, except for an earlier decrease in absorption efficiency by $S$ oysters occurring the month before the mortality. Respiration and absorption efficiency differences could have resulted in an unfavourable net energy balance in the $S$ oysters. Temperature increase, spawning and/or other adverse factors could enhance this imbalance. Bourles (2004) showed that the respiration rates increased by a factor of nearly 2 over $48 \mathrm{~h}$ during a partial spawning. Such increases in energy demand when stored glycogen is at a low level in summer (Maurer et Comps, 1986; Li et al., 2000; Berthelin et al., 2000) could weaken the organism.

\subsection{Energy storage and fluxes}

Possible differences in the storage and dynamics of total glucose and AEC were investigated. Results showed that these parameters decreased in a similar pattern and level for the $\mathrm{R}$ and $\mathrm{S}$ groups during the period preceding summer mortality whatever the dietary ration supplied.

Total glucose and AEC described apparent energy stores but not fluxes. However, the first molecular results showed that some $\mathrm{S}$ oyster genes coding for glucose $6 \mathrm{P}$ (Hexokinase, phosphoglucomutase and phosphoenolpyruvatecarboxy kinase) had significantly lower mRNA abundance compared with results from $\mathrm{R}$ oysters during the period immediately preceding summer mortality. This was not observed in other months (Bacca pers.comm.) and suggests a difference in glucose flux regulation between the two groups in the month before the mortality episode. This difference might not be permanent in the $S$ oyster, but could result from a specific response of these oysters to an external temporal factor such as a stress or infection. Glucose 6P plays a major role in metabolism, especially to rapidly provide energy to meet cell requirements. When stored glycogen is nearly used up and energy demand increases with temperature and reproductive activity, a difference in glucose uptake capacity from food or from amino acid neoglucogenesis could be critically important for coping with stress or pathogens.

\subsection{Hemocyte characteristics in $R$ and $S$ groups}

Oyster hemocyte responses were investigated during the critical period preceding summer mortality. Bacterial species may have various, even opposing, effects on the immune response of bivalve hemocytes (Bramble and Anderson, 1997; Lambert and Nicolas, 1998; Cheng, 2000; Canesi et al., 2002; Lambert et al., 2003). It is therefore difficult to interpret the different hemocyte activities observed during the period preceding the mortality event or to conclude there was possibly a better immune response of $\mathrm{R}$ hemocytes compared to $\mathrm{S}$. However, a comparison of hemocyte activities between $\mathrm{R}$ and $\mathrm{S}$ oysters from the controlled diet experiment, showed differences in the dynamics of several hemocyte parameters. S oysters had a higher adhesive capacity than R oysters as early as April and May, a higher level of ROS in May-June, and of hyalinocyte concentration in July just before the mortality episode. The most striking result regarding hemocyte activities was the large difference between R and S for ROS production in May and June. ROS production of S oysters was from 1.5 to > 3 times that of R oysters depending on the diet and hemocyte type. Although production of ROS after 
activation by phorbol myristate acetate (PMA) (Nakayama, Maruyama, 1998; Arumugam et al., 2000; Takahashi, Mori, 2000; Goedken, De Guise, 2004) or during phagocytosis of zymosan particles (Bachère et al., 1991; Le Gall et al., 1991; Bramble and Anderson, 1998; Lambert and Nicolas, 1998; Lambert et al., 2001) has been frequently used to estimate bivalve hemocyte competence in internal defence, in this study ROS production by hemocytes was measured after two hours incubation in sterile sea-water without any addition of PMA or zymosan. Our result could reflect a physiological disorder of the S oysters, due to a bacterial or viral infection or to an environmental stress. Since ROS are known to be microbicidal, they are also detrimental to oyster cells. The final increase in circulating hemocytes from S oysters before mortality could be linked to infection. Such results have been reported in bivalves infected with protozoans: Haplosporidium nelsoni (Ford et al., 1993), Martelia refringens (Carballal et al., 1998), Perkinsus atlanticus (Ordas et al., 2000), Bonamia ostreae (Cochennec-Laureau et al., 2003); and bacteria: Vibrio sp. (Paillard et al., 1996), Vibrio tapetis (Oubella et al., 1996). However, other factors like environmental parameters (temperature, salinity, etc.) or physiological status (reproduction, stress, etc.) could modulate the hemocyte parameters and consequently the immune system of bivalves (Fisher et al., 1990; Oliver and Fisher, 1995; Fisher et al., 1996; Carballal et al., 1998; Fisher et al., 2000; Oliver et al., 2001; Auffret et al., 2002).

\subsection{Effect of stress}

These differences in hemocyte parameters over time suggest that $\mathrm{S}$ and $\mathrm{R}$ oysters react differently to environmental stress or infection. This stimulation is detectable between one and a half months before mortality event when gametogenesis and temperature increased. Furthermore, in the field, a strong negative effect associated with sediment proximity was traced through a decrease in oyster Walne and Mann index one month before mortality occurred, and correlated with mortality rate (Soletchnik et al. 2005b). This could be due to stress by toxic compounds $\left(\mathrm{H}_{2} \mathrm{~S}, \mathrm{NH}_{3}-\mathrm{NH}_{4}{ }^{+}\right)$from the sediment during this period (Knoery et al personal communication). Several markers were tested to investigate differences in $\mathrm{R}$ and $\mathrm{S}$ oyster stress response. A significant difference was observed between $\mathrm{S}$ and $\mathrm{R}$ for HSP70 and catalase activity during an adaptation from $13^{\circ} \mathrm{C}$ to $19^{\circ} \mathrm{C}$ before the hypoxia stress experiment. This difference increased dramatically under hypoxia but did not affect $\mathrm{R}$ oysters. These observations suggest a higher susceptibility of $\mathrm{S}$ oysters compared to $\mathrm{R}$ ones to some uncontrolled experimental stress or specifically to hypoxia. The rapid temperature increase or the handling of oysters during the experiment preparation could be such an event. Increasing the temperature and food for 15 days in this period (December) is also a classic method to induce also broodstock gametogenesis. This seems to be an important aspect for understanding the specific response of $S$ oysters to stress as they invest more in gametogenesis than R oysters. It is possible that these two events had a detrimental effect on the general metabolic regulations (Piano et al., 2005). The very low level of gene expression coding for glucose 6P metabolism in $\mathrm{S}$ oysters one month before mortality in the feeding experiment can also reflect such a general disturbance. The difference in catalase response between the two groups could have some consequence in ROS detoxification processes that are generally associated to stress (Lacoste et al., 2002). It could explain the high level of ROS observed in the $\mathrm{S}$ oysters two months before mortality in the feeding experiment. It will be necessary to clarify the possible link between these two parameters with new experiments.

\subsection{Stress and gametogenesis}

Interactions between stress and reproduction described in the literature can help to explain the detrimental effects of temperature and gametogenesis for $\mathrm{S}$ oysters. Two aspects can be considered. On one hand, an immediate temporary increase in dopamine and noradrenaline was reported after acute mechanical stress on C. gigas (Lacoste et al., 2001a) with successive inhibition and activation of hemocyte activities (ROS production and phagocytosis) for two hours before these returned to their baseline (Lacoste et al. 2002). Under chronic stress, the levels of dopamine and noradrenaline appeared to be maintained above the baseline for a longer time (Lacoste 2001b). On the other hand, spawning can be induced by thermal shock in bivalves (Barber and Blake, 1991) but there is conflicting evidence for the involvement of catecholamines in reproduction especially for spawning (Mori et al., 1972; Matsunami and Nomura, 1987; Osada et al., 1992; Smith and Croll, 1997). While Fong et al. (1993) showed that among catecholamines, dopamine and noradrenaline reduced the positive serotonine-induced spawning in the zebra mussel, Pani and Croll (2000) showed that dopamine concentration was significantly depressed in the hemolymph of scallops which had spawned compared with unspawned controls. These observations lead us to conclude that high dopamine levels associated with stress could inhibit spawning. Such inhibition was observed for the $S$ 
oysters during gametogenesis when a sediment effect was recorded in the field, and under experimental conditions, when the higher diet induced more gametogenesis in S than in R oysters. Inversely, partial spawnings were observed for S oysters instead of a major spawning. This could result from rapid fluctuations in noradrenaline and dopamine levels, depending on stress duration and intensity, changing ratio of serotonine/ dopamine or related receptors. Moreover the high ROS content of $\mathrm{S}$ oysters and the $\mathrm{NH}_{4}{ }^{+}$from the sediment could also contribute to spawning induction. This interpretation would suggest that the difference in spawning strategy of S oyster is associated with a specific interaction between stress and gametogenesis leading to more partial spawning in $S$ than in $R$ oysters, as observed in the field and experimental data. New experiments will be necessary to study these events and mechanisms by comparison of the two groups.

\section{8 $R$ and $S$ response to experimental infection}

Experimental infections were performed either by injection or by bathing using pathogenic strains isolated following summer mortality events: Vibrio splendidus (LGP 31 and 32 Gay, 2004a, b, c) and Vibrio aestuarianus (Labreuche et al., 2005). When bacteria were injected into the muscle, R and S oysters had similar mortality rates, suggesting that they have no specific difference in their defence capacity when cellular barriers are broken by injection, or that they cannot resist such a high concentration of bacteria. This method was therefore not suitable for studying the summer mortality mechanism.

A difference in $\mathrm{R}$ and $\mathrm{S}$ oyster susceptibility was only reproduced under certain conditions using the bath method with Vibrio aestuarianus. A stress (thermal shock) was necessary prior to the bacterial challenge, and enough gametogenesis had to have taken place to distinguish $\mathrm{R}$ and $\mathrm{S}$ reproduction intensity. This was the case when a vibrio challenge was performed in May on 15-month-old oysters from the field (Rivière d'Auray), and in the controlled experiment with the high diet. The infection process was not successful for the 4 month old spat challenged in May, probably due to their lower gametogenesis at that period, compared with oysters of 18 months. In the light of the discussion above, these results suggest that stress and high gametogenesis intensity would induce partial spawnings mostly in S and would facilitate pathogen colonisation in S oysters compared with $\mathrm{R}$ ones.

\subsection{Partial spawning and the infection process}

Partial spawning, which characterized S oysters, could play a role in a differential infection process, as pathogen transmission between moribund and uncontaminated oysters was favoured during spawning events in experimental conditions with a huge increase in vibrios associated with organic matter output at spawning (Le Roux, 2004). A survey of vibrios in oyster hemolymph from the field showed that in some cases there was a significant increase just before a mortality event (Rivière d'Auray), but only minor differences were observed between $\mathrm{R}$ and $\mathrm{S}$ oysters. Bacterial increase in hemolymph was also observed after normal major spawning of oysters in Marennes a month after the mortality period and with no associated mortality. However hemolymph microflora was highly diverse in both cases (Nicolas, unpublished). These results demonstrated that bacteria can colonise oyster hemolymph in the last month before mortality at the same time as partial spawning events or later, during full spawning. However would only be detrimental if there were pathogenic strains in the microflora. In the field, preliminary observations are being undertaken to check the environmental microflora composition and diversity in the surrounding sea water, sediment and oyster palleal cavity when partial spawnings are observed. S oysters demonstrating partial spawning earlier than $\mathrm{R}$ oysters would also be infected before $\mathrm{R}$ oysters, and probably to a greater extent because vibrio number increased on gametic organic matter. 


\section{Conclusion}

A difference in the reproductive status of $R$ and $S$ oysters appeared to be a key factor in the differential response to infection. But even if the energy decrease associated with reproduction intensity and temperature plays a role in summer mortality, the measured differences in reproduction intensity and in related respiration rates were quite small. These could not explain phenotypic differences between R and S except if other events, such as stress or spawning events, accentuate the energetic imbalance. After a temperature increase associated to gametogenesis $\mathrm{S}$ oysters appeared highly susceptible to stress compared to $\mathrm{R}$ oysters. This high sensitivity to hypoxia is interesting as the sediment effect could correspond to low partial hypoxia and consequently $\mathrm{H}_{2} \mathrm{~S}$ diffusion and toxicity. Catalase lower and constant level in $\mathrm{S}$ group compared to $\mathrm{R}$ one, whatever the further stress conditions could explain the ROS increase in stressed S oysters. The low response to further stress would be the consequence of the first perturbation. Further studies are necessary to measure catecholamines in $\mathrm{R}$ and $\mathrm{S}$ groups and detect a possible hormonal imbalance and a resulting spawning depression due to stressors. For the moment our data suggest that spawning inhibition of $S$ oysters results from their specific stress reaction. These results also suggest that the partial spawning characterizing mature $S$ oysters could occur specifically in this group due to competition between such spawning inhibition and a possible spawning induction by high ROS levels and/or $\mathrm{NH}_{4}{ }^{+}$from the sediment. The partial spawnings of $S$ oysters would increase respiration and energetic imbalance and thus open a physical possibility for pathogen contamination. $S$ oysters would be contaminated earlier than $\mathrm{R}$ ones when pathogens were present in the microflora. The final increase in hyalinocyte concentration, observed just before the mortality event, would have resulted from this last infection process. Perturbations in absorption efficiency were detected earlier in S oysters and could be associated with specific infection of the digestive gland affecting cellular integrity, as observed in Arcachon (Maurer and Comps 1986) or with a sediment effect on ingestion rate. The specific decrease in glucose metabolism could be a secondary event of this infection. At present we cannot exclude the possibility of another infection mechanism or lethal metabolic disturbance resulting from the regulation conflict between catecholamines and S-oyster-specific control of reproduction and immunity, and further investigations are necessary to draw conclusions about this aspect.

Towards an integrated approach: Today, molecular tools allow us to examine differences in gene expression and related proteins or peptides. The first steps have been performed to produce a SSH library (Huvet et al. 2004) and prepare macro-arrays then micro-arrays to screen available EST expression levels in different biological situations (Boulot, pers. comm.). The first results provided a number of candidate genes that should be validated using real time PCR and tested with more experiments. The high heritability of resistance to summer mortality would suggest that a very limited number of genes are directly concerned and this is an important factor considering the complexity of the interactions between oysters, their environment and opportunistic pathogens.

\section{Acknowledgments}

The authors are grateful to all the contributors involved in the Morest project for their support during the course of this work. We are indebted to $\mathrm{H}$. McCombie-Boudry for her help with English language editing. We thank L. Dégremont for providing the parental oysters and all the staff of Argenton (especially P. Le Souchu, J.P. Connan and I. Quéau) and Bouin (especially M. Nourry) stations for providing experimental oysters under controlled conditions. We also thank all the staff of $\mathrm{La}$ Tremblade, La Trinité and Port en Bessin for their active participation in the maintenance of oysters in the field. This work was supported by the Régions of Basse-Normandie, Bretagne, Pays de la Loire, Poitou-Charentes, by the Conseil Général du Calvados, IFOP from EU and by the national Morest project funded by Ifremer. 


\section{References}

Arumugam, M., Romestand, B., Torreilles, J., 2000. Nitrite released in haemocytes from Mytilus galloprovincialis, Crassostrea gigas and Ruditapes decussatus upon stimulation with phorbol myristate acetate. Aquat. Living Resour. 13, 173-177.

Auffret, M., Mujdzic, N., Corporeau, C., Moraga, D., 2002. Xenobiotic-induced immunomodulation in the European flat oyster, Ostrea edulis. Mar. Environ. Res. 54, 585-589.

Barber, F.J., and Blake, N.J., 1991. Reproductive physiology. In "Scallops : Biology, Ecology and aquaculture" (S.E.Shumway, Ed.), 377-428.Elsevier, Amsterdam.

Bacca, H., Huvet, A., Fabioux, C., Daniel, JY., Delaporte, M., Pouvreau, S., Van Wormhoudt, A., Moal, J., 2005. Molecular cloning and seasonal expression of the oyster glycogen phosphorylase and glycogen synthase genes. Comp. Biochem. Physiol., 140B, 635-646.

Bachère, E., Hervio, D., Mialhe, E., 1991. Luminol-dependent chemiluminescence by hemocytes of two marine bivalves, Ostrea edulis and Crassostrea gigas. Dis. Aquat. Organ. 11, 173-180.

Beattie, J.H., Chew, K.K. and Hershberger, W.K., 1980. Differential survival of selected strains of Pacific oysters (Crassostrea gigas) during summer mortality. Proc. Nat. Shellfish. Ass., 70, 184-189.

Berthelin, C., Kellner, K. and Mathieu, M., 2000. Storage Metabolism in the Pacific Oyster (Crassostrea Gigas) in Relation to Summer Mortalities and Reproductive Cycle (West Coast of France), Comp. Bioch. Physiol. 125 B, 359-369.

Bourles, Y., 2004. Ecophysiologie de l'huître creuse : Analyse bioénergétique de la gamétogenèse sous trois conditions trophiques distinctes. DEA Biologie et Productions Animales, Université de Rennes 1. 20p.

Boutet, I., Tanguy, A., Rousseau, S., Auffret, M., Moraga, D., 2003. Molecular identification and expression of heat shock cognate (hsc70) and heat shock protein 70 (HSP70) genes in the Pacific oyster Crassostrea gigas. Cell Stress Chaperon. : Vol.8, 1, 76-85

Bramble, L.H., Anderson, R.S., 1998. A comparison of the chemiluminescent response of Crassostrea virginica and Morone saxatilis phagocytes to zymosan and viable Listonella anguillarum. Develop. Comp. Immunol. 22, 55-61.

Bradford, M.M., 1976. A rapid and sensitive method for the quantitation of microgram quantities of protein utilizing the principle of protein dye-binding. Anal. Biochem. 72, 248-254.

Bricelj, V.M., Ford, S.E., Borrero, F.J., Perkins, F.O., Rivara, G., Hillman, R.E., Elston, R.A. and Chang, J., 1992. Unexplained mortalities of hatchery-reared, juvenile oysters, Crassostrea virginica (Gmelin). J. Shellfish Res., 11, 331-347.

Canesi, L., Gallo, G., Gavioli, M., Pruzzo, C. 2002. Bacteria-hemocyte interactions and phagocytosis in marine bivalves. Microsc. Res. Techniq. 57: 469-476

Carballal, M.J., Villalba, A., Lopez, C., 1998. Seasonal variation and effects of age, food availability, size, gonadal development, and parasitism on the hemogram of Mytilus galloprovincialis. J. Invertebr. Pathol. 72, 304-312.

Cheney, D.P., MacDonald, B.F. and Elston, R.A., 2000. Summer mortality of Pacific oysters, Crassostrea gigas (Thunberg): initial findings on multiple environmental stressors in Puget Sound, Washington, 1998. J. Shellfish Res., 19, 353-359.

Cheng, T.C., 2000. Cellular Defense Mechanisms in Oysters. In: Fingerman M, Nagabhushanam R (eds) Recent Advances in Marine Biotechnology: Immunobiology 
and Pathology. Sciences Publishers, Inc., Enfield (NH), USA; Plymouth, UK, pp 43-83

Choquet, G., Soudant, P., Lambert, C., Nicolas, J.-L., Paillard, C., 2003. Reduction of adhesion properties on Ruditapes philippinarum hemocytes exposed to Vibrio tapetis. Dis. Aquat. Organ. 57, 109-116.

Cochennec-Laureau, N., Auffret, M., Renault, T., Langlade, A., 2003. Changes in circulating and tissue-infiltrating hemocyte parameters of European flat oysters, Ostrea edulis, naturally infected with Bonamia ostreae. J. Invertebr. Pathol. 83, 23-30.

Conover, R.J.,1966. Assimilation of organic matter by zooplankton. Limnol.Oceanog.11: 338-345.

de Jong-Brink, M., Bergamin-Sassen, M. and Solis Soto, M. 2001. Multiple strategies of schistosomes to meet their requirements in the intermediate snail host, Parasitology 123, pp. 129-141.

Dégremont, L., Bédier, E., Soletchnik, P., Ropert, M., Joly, JP., Huvet, A., Moal, J., Samain, JF., Boudry, P. 2005.Variability of survival, growth and yield of hatchery-produced Pacific oyster spat (Crassostrea gigas). Relative importance of family, site and field placement timing on survival, growth and yield of hatchery-produced Pacific oyster spat (Crassostrea gigas). Aquaculture 249: 213-229.

Delaporte, M., Soudant, P., Moal, J., Lambert, C., Quere, C., Miner, P., Choquet, G., Paillard, C., Samain, JF., 2003. Effect of a mono-specific algal diet on immune functions in two bivalve species - Crassostrea gigas and Ruditapes philippinarum. J. Exp. Biol.Ecol. 206, 3053-3064.

Delaporte, M., 2005. Modulation des paramètres hémocytaires par la nutrition chez l'huître creuse Crassostrea gigas. Implication dans les mortalités estivales. Phd Thesis in Biology. Université de Rennes 1. 362 pp. (in French). France.

Delaporte, M., Soudant, P., Lambert, C., Moal, J., Pouvreau, S., Samain, J.F. (2006). Impact of food availability on energetic storage and related hemocyte parameters of the Pacific oysters Crassostrea gigas during an experimental reproductive cycle. Aquaculture 254, 571-582.

Dubois, M., Gilles, K.A., Hamilton, J.K., Rebers, P.A. and Smith, F., 1956. Colorimetric method for determination of sugars and related substances. Anal. Chem., (28) 350-356.

Elston, R.A., Beattie, J.H., Friedman, C., Hedrick, R. and Kent, M.L., 1987. Pathology and significance of fatal inflammatory bacteraemia in the Pacific oyster, Crassostrea gigas Thunberg. J. Fish Dis., 10, 121-132.

Ernande, B., Boudry, P., Clobert, J., Haure, J., 2004. Plasticity in resource allocation based life history traits in the Pacific oyster, Crassostrea gigas. I Spatial variation in fund abundance. J. Evol. Biol. 17: 342-356.

Enriquez-Diaz, M., 2004. Variabilité bioénergétique de la reproduction chez l'huître creuse Crassostrea gigas. Phd thesis. Université de Bretagne Occidentale. 150 pp. (in French), France.

Fisher, W.S., Wishkovsky, A., Ford, S.E., 1990. Effects of tributyltin on defense-related activities of oyster hemocytes. Arch. Environ. Contam. Toxicol. 19, 354-360.

Fisher, W.S., Leah, M.O., Edwards, P., 1996. Hematologic and serologic variability of eastern oysters from Apalachicola Bay, Florida. J. Shellfish Res. 15, 555-564.

Fisher, W.S., Oliver, L.M., Winstead, J.T., Long, E.R., 2000. A survey of oysters Crassostrea virginica from Tampa Bay, Florida: associations of internal defense measurements with contaminant burdens. Aquat. Toxicol. 51, 115-138. 
Fong P.P., Noordhuis R., Ram J.L., 1993. Dopamine reduces intensity of serotonin-induced spawning in the zebra mussel Dreissena polymorpha (Pallas). J. Exp.Zool., 266, (1), 79-83)

Ford, S.E., Ashton-Alcox, K.A., Kanaley, S.A., 1993. In vitro interaction between bivalve hemocytes and the oyster pathogen Haplosporidium nelsoni (MSX). J. Parasitol. 79, 255-265.

Ford, S.E. and Borrero, F.J., 2001. Epizootiology and pathology of Juvenile Oyster Disease in the Eastern Oyster, Crassostrea virginica. J. Invertebr. Pathol., 78, 141-154.

Friedman, C.S., Beaman, B.L., Chun, J., Goodfellow, M., Gee, A. and Hedrick, R.P., 1998. Nocardia crassostreae sp. nov., the causal agent of nocardiosis in Pacific oysters. Int. J. System. Bacteriol., 48, 237-246.

Friedman, C.S., Beattie, J.H., Elston, R.A. and Hedrick, R.P., 1991. Investigation of the relationship between the presence of a Gram-positive bacterial infection and summer mortality of the Pacific oyster, Crassostrea gigas Thunberg. Aquaculture, 94, 1-15.

Friedman, C.S., Estes, R.M., Stokes, N.A., Burge, C.A., Hargove, J.S., Barber, B.J., Elston, R.A., Burreson, E.M. and Reece, K.S., 2005. Herpes virus in juvenile Pacific oysters Crassostrea gigas from Tomales Bay, California, coincides with summer mortality episodes. Dis. Aquat. Org., 63, 33-41.

Gay, M., Renault, T., Pons, A.M., Le Roux, F.2004a.Two vibrio splendidus related strains collaborate to kill Crassostrea gigas: taxonomy and host alterations.

Dis Aquat Organ. 23;62(1-2):65-74.

Gay, M., Berthe, F.C., Le Roux, F.2004b. Screening of Vibrio isolates to develop an experimental infection model in the Pacific oyster Crassostrea gigas.

Dis Aquat Organ. 2004 Apr 21;59(1):49-56.

Gay, M. 2004c. Infection expérimentale chez Crassotrea gigas : étude de deux souches pathogènes apparentées à Vibrio splendidus. Thèse d'Université La Rochelle, France. 214pp.

Glude, J.B., 1975. A summary report of the Pacific Coast oyster mortality investigations 1965-1972. Proceedings of the Third U.S.-Japan Meeting on Aquaculture at Tokyo, Japan, October 15-16, 1974. p.28.

Goedken, M., De Guise, S., 2004. Flow cytometry as a tool to quantify oyster defence mechanisms. Fish and Shellfish Immunolo. 16, 539-552.

Goulletquer, P., Soletchnik, P., Le Moine, O., Razet, D., Geairon, P., Faury, N., and Taillade, S., 1998. Summer morality of the Pacific cupped oyster Crassostrea gigas in the Bay of MarennesOleron (France). ICES Mariculture Committee CM 1998/CC. pp. 14-21.

Greenwald R.A., 1985. Handbook of methods for oxygen radical research. CRC Press, Boca Raton, FL.

Héral, M., Deslous-Paoli, J.M., 1991. Oyster culture in European countries. In : Estuarine and marine bivalve mollusk culture.CRC Press, Menzel, W.(Ed.), Boca Raton 153-190.

Hershberger, W.K., Perdue, J.A. and Beattie, J.H. 1984. Genetic selection and systematic breeding in pacific oyster culture. Aquaculture, $39: 237-245$.

Huvet, A., Herpin, A., Dégremont, L., Labreuche, Y., Samain, J.F., Cunningham, C. 2004. The identification of genes from the oyster Crassostrea gigas that are differentially expressed in progenies exhibiting opposed susceptibility to summer mortality. Gene, 343, 211-220.

Kalra, S.P. and Kalra, P.S., 2004. NPY an endearing journey in search of neurochemical on/off switch for appetite, sex and reproduction. Peptides, 25, 3, 465-471. 
Koganezawa, A., 1974. Present status of studies on the mass mortality of cultured oysters in Japan and its prevention. In: (Ed.), Third U.S.-Japan Meeting on Aquaculture, Tokyo, Japan. Journal, 29-34.

Labreuche, Y., Soudant, P., Gonçalves, M., Lambert, C., and Nicolas, J.L., 2006. In vitro effects of Extracellular Products (ECPs) from the pathogenic Vibrio aestuarianus strain 01/32 on the oyster Crassostrea gigas cellular immune responses. Dev. Comp. Immunol. 30, 4, 367-379.

Lambert, C., Nicolas, J.L.,1998. Specific inhibition of chemiluminescent activity by pathogenic Vibrios in hemocytes of two marine bivalves: Pecten maximus and Crassostrea gigas. J. Invertebr. Pathol. 71, 53-63.

Lambert, C., Nicolas, J.L., Bultel, V., 2001. Toxicity to bivalve hemocytes of pathogenic vibrio cytoplasmic extract. J. Invertebr. Pathol. 77, 165-172.

Lambert, C., Soudant, P., Choquet, G., Paillard, C., 2003. Measurement of Crassostrea gigas hemocyte oxidative metabolism by flow cytometry and the inhibiting capacity of pathogenic vibrios. Fish and Shellfish Immunol. 15, 225-240.

Lacoste, A., Malham, S.K., Cueff, A., Poulet, S.A., 2001a. Stress and stress-induced neuroendocrine changes increase the susceptibility of juvenile oysters (Crassostrea gigas) to Vibrio splendidus. Appl Environ Microbiol.; 67:2304-2309.

Lacoste, A., Malham, S.K., Cueff, A., Poulet, S.A., 2001b. Stress-induced catecholamine changes in the hemolymph of the oyster Crassostrea gigas. Gen. Comp. Endocrinol. 122, 181-188.

Lacoste, A., Malham, S.K., Gélébart, F., Cueff, A., Poulet, S.A., 2002. Stress-induced immune changes in the oyster Crassostrea gigas. Dev. Comp. Immunol., 26, 1-9.

Landgon, C., Evans, F., Jacobson, D., Blouin, M. 2003. Yields of cultured Pacific oysters Crassostrea gigas Thunberg improved after one generation of selection. Aquaculture 220, 227-244.

Lee, M., Taylor, G.T., Bricelj, V.M., Ford, S.E. and Zahn, S., 1996. Evaluation of Vibrio spp. and microplankton blooms as causative agents of Juvenile Oyster Disease in Crassostrea virginica (Gmelin). J. Shellfish Res., 15, 319-329.

Le Gall, G., Bachère, E., Mialhe, E., 1991. Chemiluminescence analysis of the activity of Pecten maximus hemocytes stimulated with zymosan and host-specific rickettsiales-like organisms. Dis. Aquat. Organ. 11, 181-186.

Le Roux, F., Gay, M., Lambert, C., Waechter, M., Poubalanne, S., Chollet, B., Nicolas, J.L., and Berthe, F., 2002. Comparative analysis of Vibrio splendidus-related strains isolated during Crassostrea gigas mortality events. Aquat. Living Resour., 15 : 251-258.

Le Roux, F., Gay, M., Lambert, C., Nicolas, J.L., Gouy, M. and Berthe F., 2004. Phylognetic study and identification of Vibrio splendidus related strains based on GyrB gene sequences. Dis. Aquat. Organ. 58,143-150.

Le Roux, F., 2004 . Taxonomie et virulence de vibrions pathogènes d'huîtres creuses Crassostrea gigas. Habilitation à Diriger des Recherches Université Paris VI.

Lewis, E.J., Farley, C.A., Small, E.B. and Baya, A.M., 1996. A synopsis of juvenile oyster disease (JOD) experimental studies in Crassostrea virginica. Aquat. Living. Resour.., 9, 169-178.

Li, Q., Osada, M. and Mori, K., 2000. Seasonal Biochemical Variations in Pacific Oyster Gonad Tissue During Sexual Maturation, Fisheries Sci. 66, 502-508. 
Lipovsky, V.P. and Chew, K.K., 1972. Mortality of Pacific oysters Crassostrea gigas: the influence of temperature and enriched seawater on survival. Proc. Nat. Shellfish. Ass., 62, 72-82.

Lowry, O.H., Rosebrough, N.J., Farr, A.L., Randall, R.J., 1951. Protein measurement with the Folin phenol reagent. J Biol Chem 193, 251.

Martoja, R. and Martoja-Pierson, M., 1967. Initiation aux techniques de l'histologie animale. Masson et Cie Paris.

Maurer, D., Comps, M., 1986. Summer mortality of oysters Crassostrea gigas in the Bay of Arcachon : environmental biochemical and histological aspects. In Pathology in Marine Aquaculture, C.P.Vivares, J.R. Bonami, and E.Jaspers (Eds). European Aquaculture Society, Special publication $n^{\circ} 9$, Bredene, Belgium.

Moal, J., Le Coz, J.R., Samain, J.F. \& Daniel, J.Y.,1989. Nucleotides in bivalves: extraction and analysis by high -performance liquid chromatography (HPLC). Comp. Biochem. Physiol., (93 B) 307-316.

Mori, K., 1979. Effects of artificial eutrophication on the metabolism of the Japanese oyster Crassostrea gigas. Mar. Biol., 53, 361-369.

Matsunami, T. and Nomura, T.,1986. Pharmacological observations on the mechanism of spawning in the scallop Patinopecten yessoensis. Bull.Jpn.Soc.Sci.Fish.52, 1589-1594.

Nakayama, K. and Maruyama, T., 1998. Differential production of active oxygen species in photosymbiotic and non-symbiotic bivalves. Develop. Comp. Immunol. 22, 151-159.

Oliver, L.M.and Fisher, W.S., 1995. Comparative form and function of oyster Crassostrea virginica hemocytes from Apalachicola Bay, Florida and Chesapeake Bay (Virginia). Dis. Aquat. Organ. 22, 217-225.

Oliver, L.M., Fisher, W.S., Winstead, J.T., Hemmer, B.L., Long, E.R., 2001. Relationships between tissue contaminants and defense-related characteristics of oysters (Crassostrea virginica) from five Florida bays. Aquat. Toxicol. 55, 203-222.

Ordas, M.C., Ordas, A., Beloso, C., Figueras, A., 2000. Immune parameters in carpet shell clams naturally infected with Perkinsus atlanticus. Fish Shellfish Immun. 10, 597-609.

Osada, M., Mori, K., Nomura, T., 1992. In vitro effects of estrogen and serotonin on release of eggs from the ovary of the scallop. Nippon Suisan Gakkaishi 58, 223-227.

Oubella, R., Maes, P., Allam, B., Paillard, C., Auffret, M., 1996. Selective induction of hemocytic response in Ruditapes philippinarum (Bivalvia) by different species of Vibrio (Bacteria). Aquat. Living Resour. 9, 137-143.

Paillard, C., Ashton-Alcox, K.A., Ford, S.E., 1996. Changes in bacterial densities and hemocyte parameters in eastern oysters, Crassostrea virginica, affected by juvenile oyster disease. Aquat. Living Resour.9, 145-158.

Pani A.K. and Croll R.P., 2000. Catechol concentration in the hemolymph of the scallop, Placopecten magellanicus. Gen. Comp. Endocr. 118, 48-56.

Perdue, J.A., Beattie, J.H. and Chew, K.K., 1981. Some relationships between gametogenic cycle and summer mortality phenomenon in the Pacific oyster (Crassostrea gigas) in Washington state. J. Shellfish Res., 1, 9-16. 
Piano, E., Bertoli, F. B., Romani, M., Tava, A., Riccioni, L., Valvassori, M.,. Carroni, A. M and Pecetti, L., 2005. Specificity of Host-Endophyte Association in Tall Fescue Populations from Sardinia, Italy.

Crop Sci 45:1456-1463.

Pouvreau, S., Enriquez-Diaz, M., Le Souchu, P. Connan, JP. Le Roy, B. Mingant, C. Moal, J. Delaporte, M. Le Coz, JR. Samain, J.F., 2003. Reproduction, bioenergetic and summer mortality of Crassostrea gigas: Experimental approach. J. Shellfish Res.. Vol. 22, no. 1, p. 351.

Renault, T., Le Deuff, R.M., Cochennec, N. and Maffart, P., 1994. Herpesvirus associated with mortalities among Pacific oyster, Crassostrea gigas, in France - Comparative study. Rev. Méd. Vét., 145 (10) : 735-742.

Samain, J.F., Boudry, P., Degremont, L., Soletchnik, P., Ropert, M., Bedier, E., Martin, J.L., Moal, J., Mathieu, M., Pouvreau, S., Lambert, C. Escoubas, J.M. Nicolas, J.L., Le Roux, F.,2004a. Summer mortality in the Pacific oyster Crassostrea gigas, overview of 3-year results of the cooperative "MOREST" Project. J. Shellfish Res. 23 (1): 309-310.

Samain J.F., Boudry, P., Degremont, L., Soletchnik, P., Ropert, M., Bedier, E., Moal, J., Mathieu, M., Lambert, C., Escoubas, J.M., Nicolas, J.L., Le Roux, F., Bacher, C., Renault T., and Burgeot T., 2004b. The programme Morest (Summer mortality of Crassostrea gigas oyster)] Plouzane (France), Ifremer.23-30. Actes de colloques. Institut Français de Recherche pour l'Exploitation de la Mer [in Styli 2003 Actes Colloq.38 IFREMER]. 2004. p.23-30

Shaw, B.L., and Battle, H.I., 1957. The gross and microscopic anatomy of the digestive tract of the oyster Crassostrea virginica (Gmelin). Can. J.Zool. 35, 325-347.

Smith, S.A., Nason, J., Croll, R.P., 1998. Distribution of catecholamines in the sea scallop, Placopecten magellanicus. Can.J.Zool. 76, 1254-1262.

Soletchnik, P., Razet, D., Geairon, P., Faury, N., and Goulletquer, P., 1997. Ecophysiology of maturation and spawning in oyster (Crassostrea gigas): Metabolic (respiration) and feeding (clearance and absorption rates) responses at different maturation stages. Aquat. living resour. 10: 177-185.

Soletchnik, P., Le Moine, O., Faury, N., Razet, D., Geairon P., and Goulletquer P., 1999. Summer mortality of the oyster in the Bay Marennes-Oleron: Spatial varaiability of environnement and biology using a geographical information system (GIS). Aquat. Living Resour. 12: 131-143.

Soletchnik, P., Ropert, M., Huvet, A., Moal, J., Degrémont, L., Bédier, E., Bouget, J.F., Dubois, B., Martin, J.L., Enrique-Diaz, M., Faury, N., Lemoine, O., Renault, T., Gagnaire, B., and Samain, J.F., 2003. Characterization of summer mortality of C. gigas in France, in relation to environmental parameters. J. Shellfish Res. 22: 354.

Soletchnik, P., Faury N., and Goulletquer P., 2005a. Seasonal changes in carbohydrate metabolism and its relationship with summer mortality of Pacific oyster Crassostrea gigas (Thunberg) in Marennes-Oléron bay (France).Aquaculture (in press).

Soletchnik P., Lambert C., and Costil K. 2005b. Summer mortality of Crassostrea gigas (Thunberg) in relation to rearing environment conditions. J Shellfish Res 241 197-207

Takahashi, K.G., Mori, K., 2000. NADPH oxidase-like activity in hemocytes of the Pacific oyster Crassostrea gigas. Fish Pathol. 35, 15-19. 
Table 1. Specific primers used for gene expression analysis.

Oyster-specific primers for real time PCR

HK Forward: 5' -AGGTCAAGATGTACCCCACCT- 3'

Reverse: 5' -TAAACCCGGAAGTTTGTCC- 3'

PGM Forward: 5' -GGGGAGGAGAGCTTGGAAC- 3' Reverse: 5' -GACCATAGGTCTGCCAGTGC- 3'

PK Forward: 5' -ACATGATTTTCGCCTCCTTC- 3'

Reverse: 5' -TCTCTGGGGGAATCTCAATG- 3'

PEPCK Forward: 5' -CATGGCGTCATGGTTGGAGC- 3'

Reverse: 5' -GTCAAGCCAGTGCTGTAGG- 3'

GS Forward: 5' -GACGCCAACGACCAAATG- 3' Reverse: 5' -TTCAGGAACTGGGGGTGA- 3'

GP Forward: 5' -AGACGGTCCCCGATGATT- 3'

Reverse: 5' -GGCAGCTCCTGGCTATCA- 3'

G6PDH Forward: 5' -GGTGGAGAAGCCGTTTGG- 3'

Reverse: 5' -CGAGGCGATTCCGTCTCT- 3' 
Fig.1 : Controlled diet experiment: cumulative mortality rate percentage for R and S oysters fed the $4 \%$ or $12 \%$ diet.

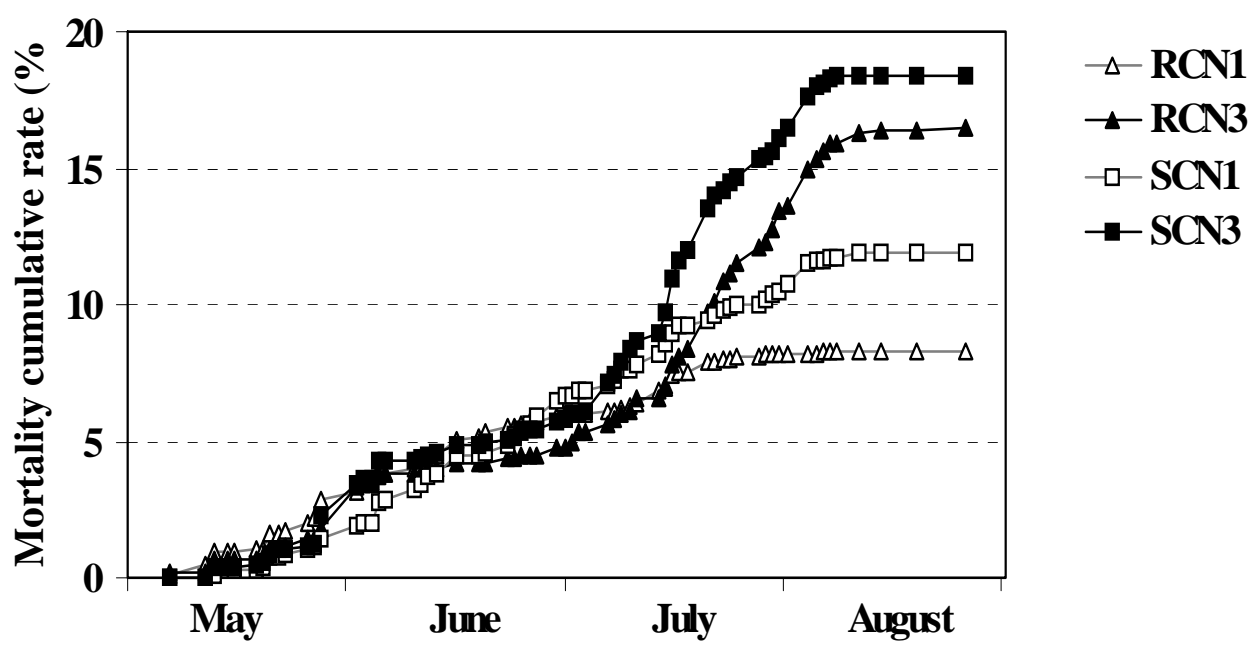


Table 2: $\mathrm{R}$ and $\mathrm{S}$ group mortality, initial and final individual weights and daily yields (means and standard deviations) observed after the summer period for the second and third generations in Rivière d'Auray.

\begin{tabular}{lllll}
\hline Generation & Parameter & R line & S line & Control \\
\hline G2 & Mortality (\%) & $7.2 \pm 3.2 \mathrm{a}$ & $43.3 \pm 12.0 \mathrm{c}$ & $23.7 \pm 6.6 \mathrm{~b}$ \\
& Initial individual weight (g) & $1.1 \pm 0.2 \mathrm{a}$ & $1.1 \pm 0.2 \mathrm{a}$ & $1.0 \pm 0.1 \mathrm{a}$ \\
& Final individual weight (g) & $9.2 \pm 0.7 \mathrm{a}$ & $8.3 \pm 1.0 \mathrm{a}$ & $8.9 \pm 0.7 \mathrm{a}$ \\
& Daily yield $\left(\% . \mathrm{d}^{-1}\right.$ ) & $7.8 \pm 0.8 \mathrm{a}$ & $4.4 \pm 1.5 \mathrm{c}$ & $6.2 \pm 0.8 \mathrm{~b}$ \\
$\mathrm{G} 3$ & Mortality (\%) & $27.1 \pm 13.1 \mathrm{a}$ & $72.5 \pm 13.4 \mathrm{c}$ & $47.8 \pm 7.9 \mathrm{~b}$ \\
& Initial individual weight (g) & $2.1 \pm 0.3 \mathrm{a}$ & $2.3 \pm 0.5 \mathrm{a}$ & $2.3 \pm 1.6 \mathrm{a}$ \\
& Final individual weight (g) & $12.9 \pm 1.4 \mathrm{a}$ & $14.7 \pm 1.5 \mathrm{a}$ & $15.7 \pm 8.0 \mathrm{a}$ \\
& Daily yield $\left(\% . \mathrm{d}^{-1}\right.$ ) & $3.3 \pm 0.7 \mathrm{a}$ & $0.8 \pm 1.0 \mathrm{c}$ & $1.8 \pm 0.7 \mathrm{~b}$ \\
\hline
\end{tabular}

Means with different superscripts differ significantly $(p<0.05)$ 
Fig.2 : Semi quantitative estimation of gonad area percentage determined by histology in $\mathrm{R}$ and $\mathrm{S}$ oysters placed in the Rivière d'Auray site in 2002 (Means and SD, * for significant difference between groups $p<0,05)$.

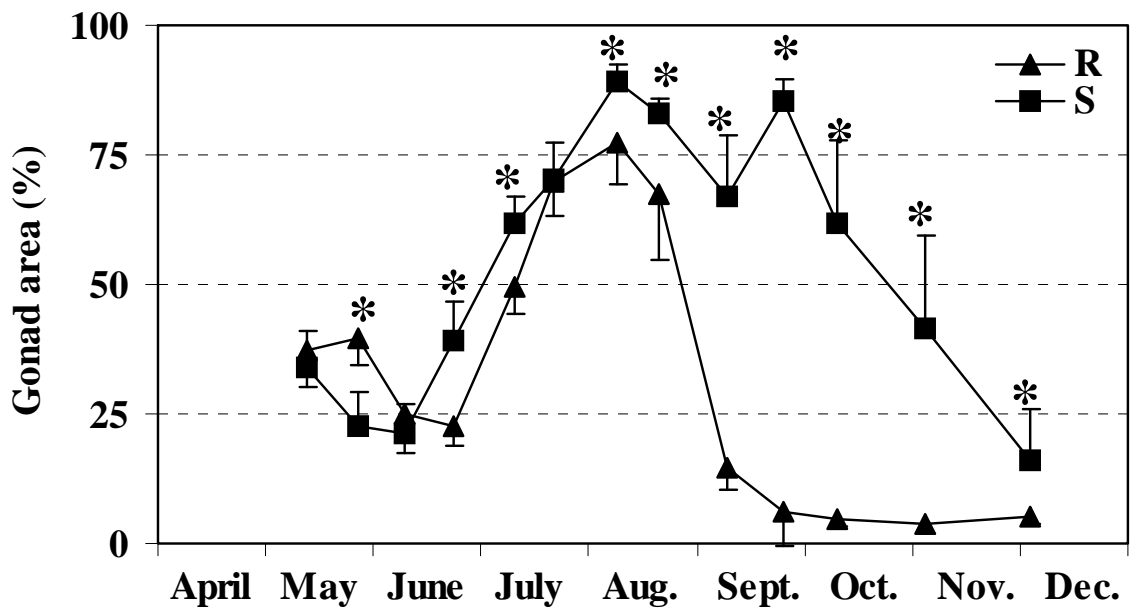


Fig.3 : Controlled diet experiment: semi quantitative estimation of gonad area percentage by histology for $\mathrm{R}$ and $\mathrm{S}$ oysters (a) fed the $4 \%$ diet or (b) fed the $12 \%$ diet (Means and SD.).

a

b

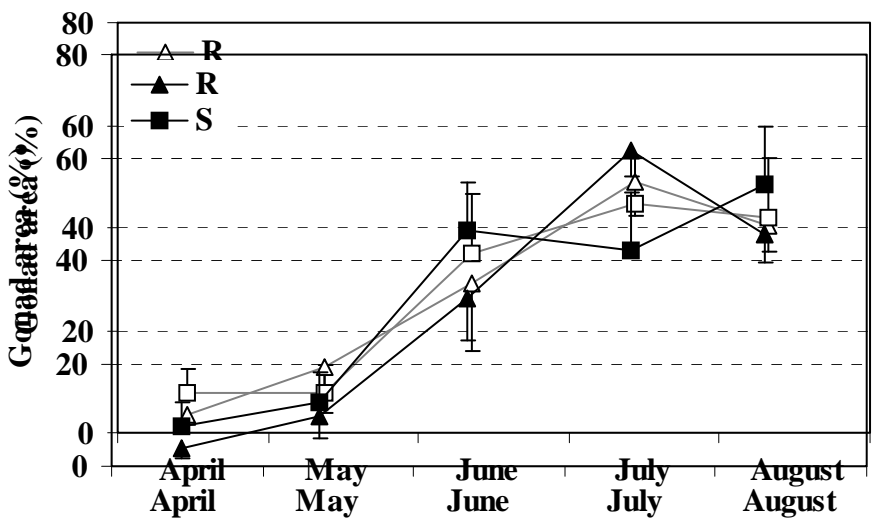


Fig.4 : Controlled diet experiment: (a) food consumption rate $\left(\mathrm{J} \cdot \mathrm{h}^{-1} \mathrm{~g}^{-1}\right)$; (b) absorption efficiency

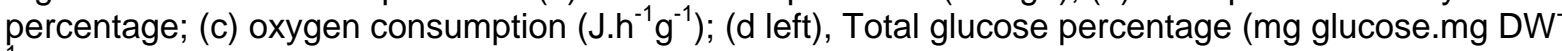
${ }^{1}$ ); (d right), Adenylic energy charge (AEC) for R and S oysters fed the $4 \%$ or $12 \%$ diet (Means and SD.).

a

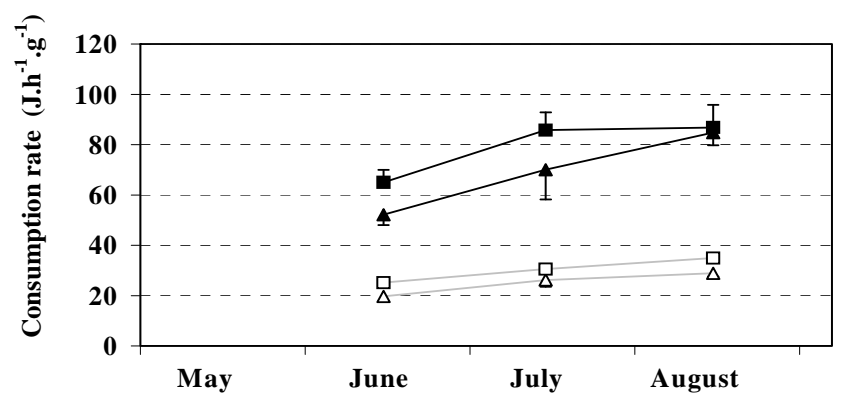

b

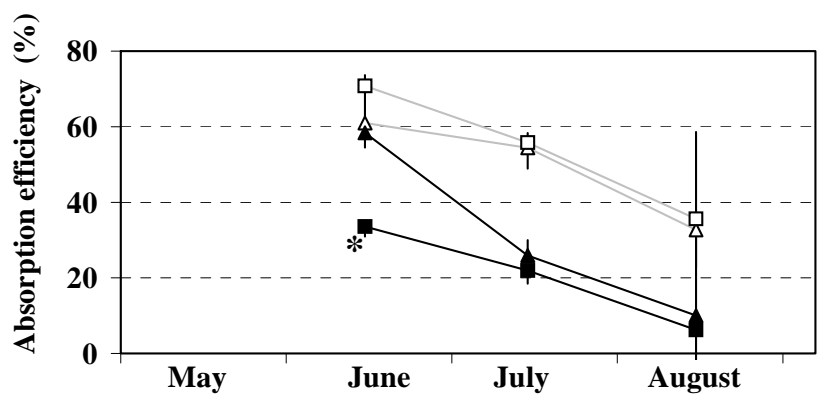

$\triangle$ CN1R

$\mp$ CN3R

- CN1S

$-\mathrm{CN} 3 \mathrm{~S}$

c

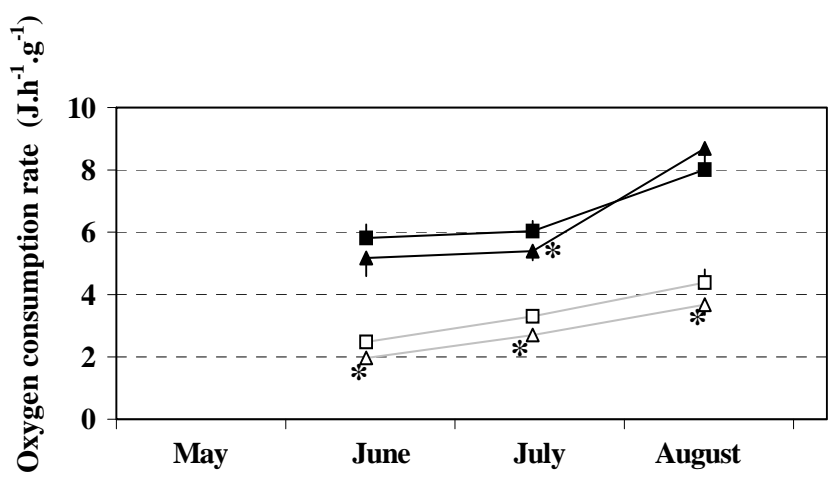

d
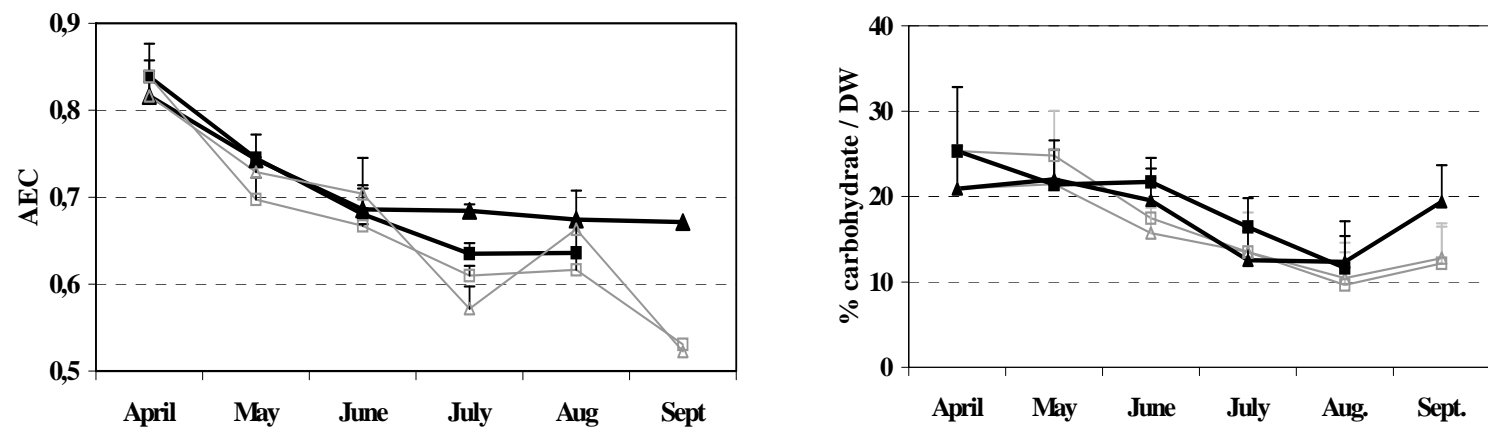
Fig.5 : Quantity (relative to G6PDH mRNA) of Hexokinase (HK), Phosphoglucomutase (PGM), Pyruvate kinase (PK), Phosphoenolpyruvate kinase (PEPCK), Glycogen Synthase (GS), and Glycogen Phosphorylase (GP) mRNAs in Resistant R oysters (white bar) and Susceptible S oysters (black bar) in labial palps in the critical period (June). Comparisons were made using a t-test at the $5 \%$ level, * indicates groups that are statistically different.

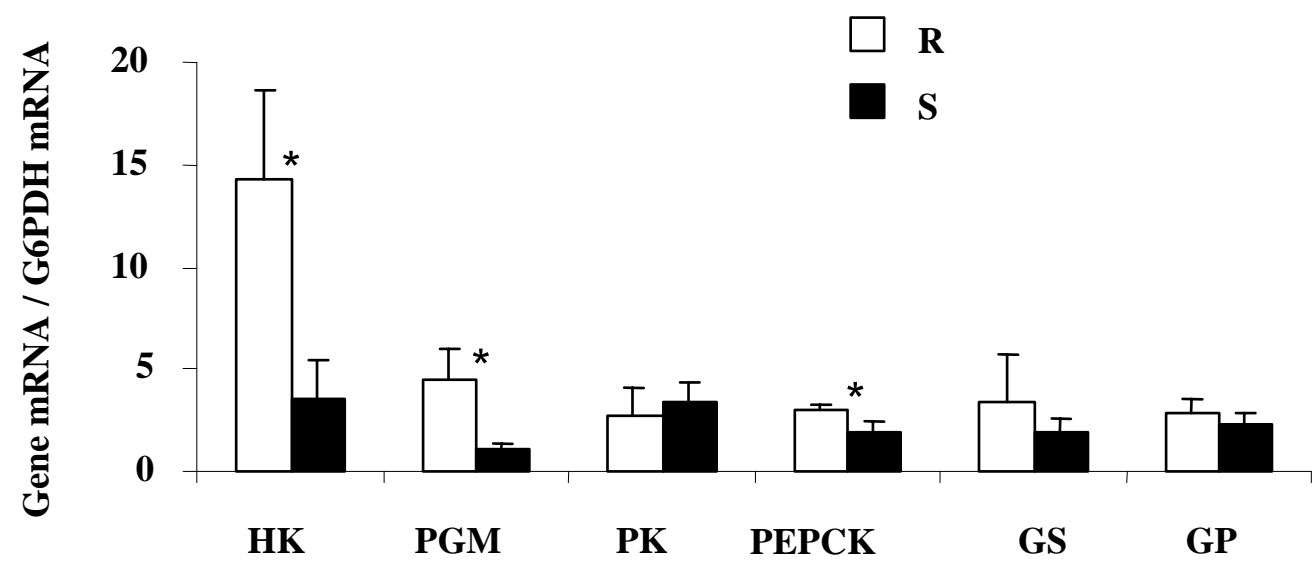


Table 3 : Comparison of hemocyte characteristics from oysters belonging to resistant $\mathrm{R}$ and Susceptible $\mathrm{S}$ groups during an experimental survey (May, June and July) around the mortality event observed mid-July. (NS: no significant differences).

\begin{tabular}{|l|l|l|l|}
\hline $\begin{array}{l}\text { Hemocyte characteristics } \\
\text { "R" versus "S" }\end{array}$ & May & June & July \\
\hline Hemocyte Adhesive capacity in SW & $\begin{array}{l}\text { S }>\mathrm{R} p=0.020 \\
\text { Kruskal-Wallis }\end{array}$ & NS & NS \\
\hline $\begin{array}{l}\text { ROS production in sea-water } \\
\text { - hyalinocytes }\end{array}$ & $\begin{array}{l}\text { S }>\mathrm{R} p=0.0001 \\
\text { Anova } \\
\text { S }>\mathrm{R} p=0.0036 \\
\text { Anova }\end{array}$ & $\begin{array}{l}\text { S>R } p=0.015) \\
\text { Kruskal-Wallis } \\
\text { S }>\mathrm{R} p=0.035) \\
\text { Kruskal-Wallis }\end{array}$ & NS \\
\hline Hyalinocyte concentration & NS & NS & $\begin{array}{l}\text { S }>\text { R } p=0.055 \\
\text { Kruskal-Wallis }\end{array}$ \\
\hline Granulocyte concentration & NS & NS & NS \\
\hline Hemocyte mortality (\% of dead cells) & NS & NS & NS \\
\hline Phagocytosis (\% of active hemocytes) & NS & NS & NS \\
\hline
\end{tabular}


Fig.6 : (a) : Heat-shock protein 70 concentration performed in the gills of R and S oysters exposed in normoxia (left), and hypoxia (right) (* significant difference between R and S p<0.05).

(b) : Catalase activity analysed in gills of $\mathrm{R}$ and $\mathrm{S}$ oysters exposed in normoxia (Left) and hypoxia (right) (* significant difference between $\mathrm{R}$ and $\mathrm{S} \mathrm{p}<0.05$ ).

a
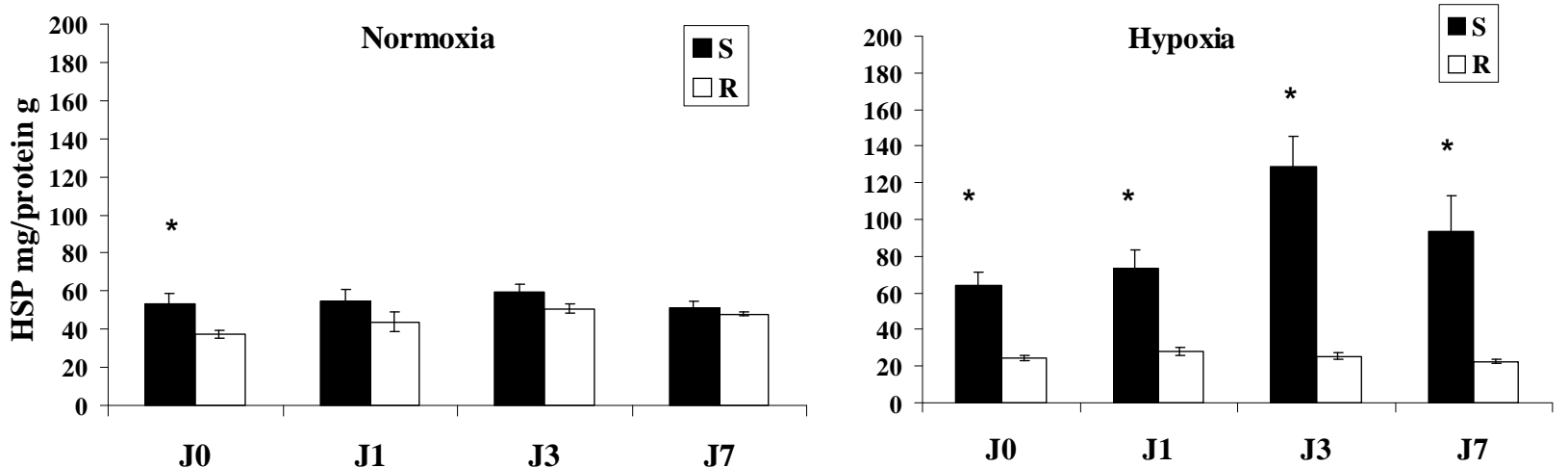

b
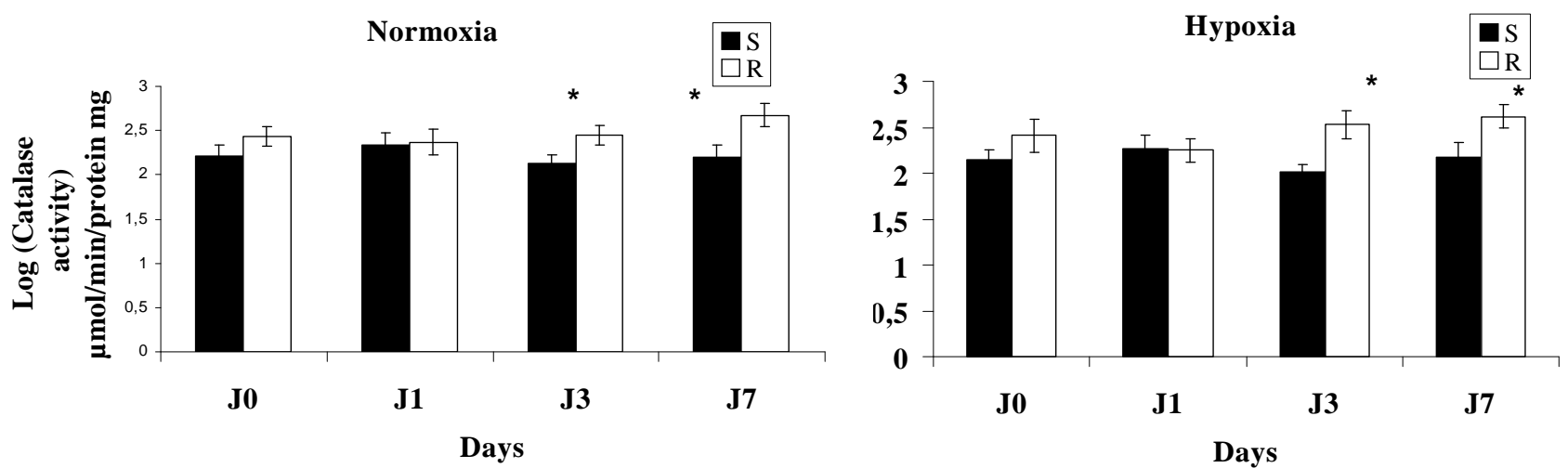
Fig.7 Infection experiments

Left : Mortality of susceptible (S) and resistant (R) oysters in 2 generations aged 4 and 15 months and placed in Auray site from February to May and then challenged by bathing with Vibrio aestuarianus.

Right : Mortality of resistant (R) and susceptible (S) oysters fed with 2 levels of microalgal diet (4\% low level; 12\% high level) during 2 months and challenged by bathing with $V$. aestuarianus.
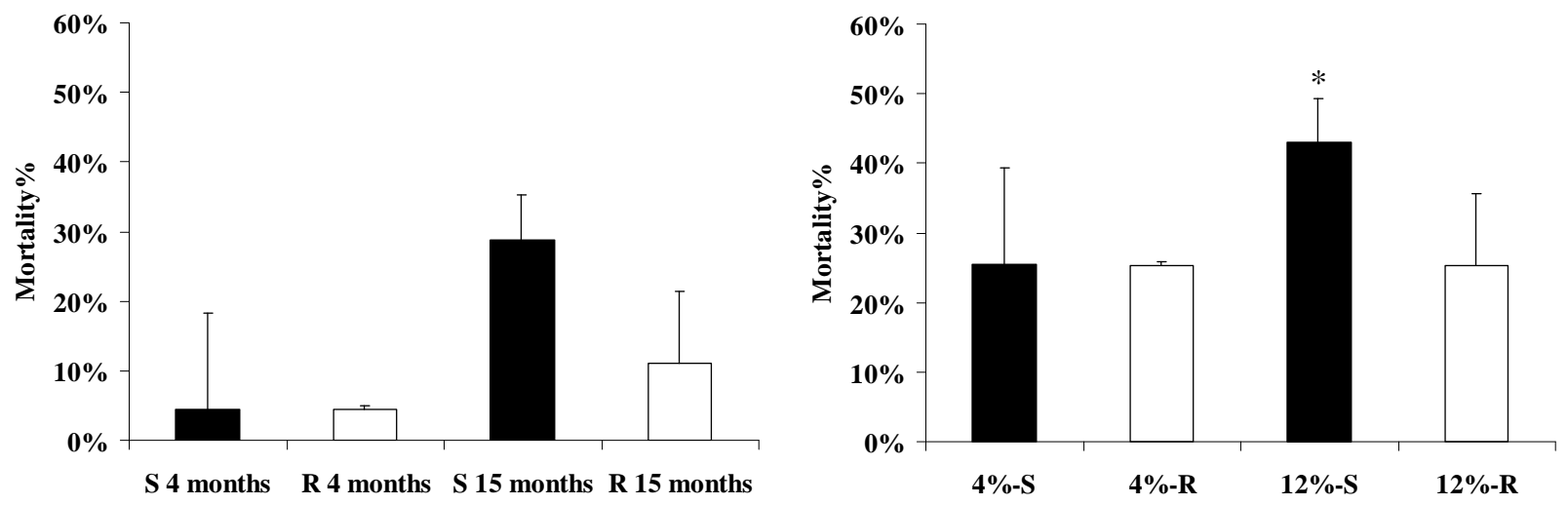
Fig.8 : Occurrence of bacteria in hemolymph of healthy oysters (R: resistant group, S: susceptible group) from May to September in the Rivière d'Auray site (2002). In September the bacterial concentrations were below $10^{2}$ cell $\mathrm{ml}^{-1}$ )

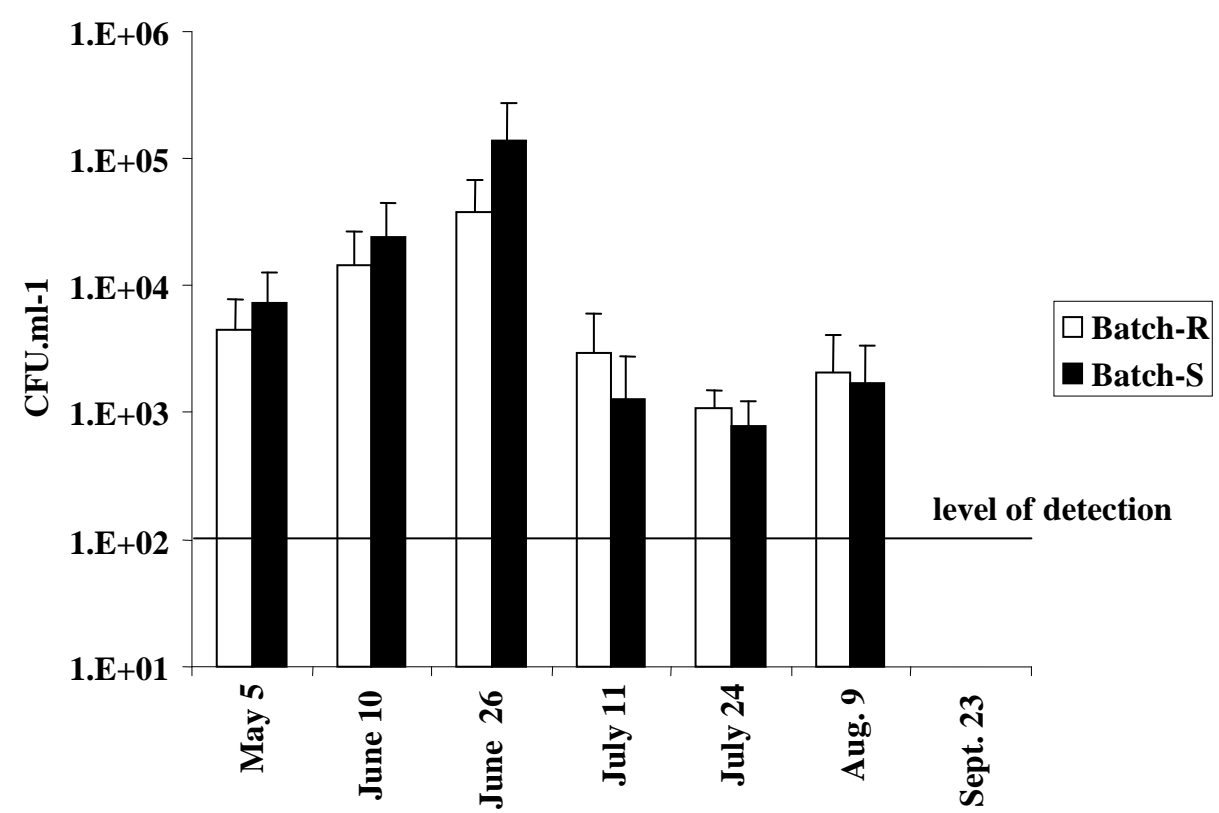

